\title{
Optimization Study on Turning Process by Using Taguchi- copras Method
} \author{
Thi Tam ${ }^{5}$, Nguyen Anh Tuan, ${ }^{2, *}$ \\ ${ }^{1}$ Ha Noi University of Industry, Vietnam \\ ${ }^{2}$ University of Economics - Technology for Industries, Vietnam \\ ${ }^{3}$ Nguyen Tat Thanh University, Ho Chi Minh City, Vietnam \\ ${ }^{4}$ Electric Power University, Vietnam \\ ${ }^{5}$ Thai Nguyen University of Technology, Thai Nguyen, Vietnam
}

Do Duc Trung ${ }^{1}$, Nguyen Huu Quang ${ }^{2}$, Tran Quoc Hoang ${ }^{3}$, Cao The Anh ${ }^{1}$, Nguyen Hong Linh ${ }^{4}$, Hoang Trung Kien ${ }^{5}$, Do

\begin{abstract}
In this article, a multi-objective optimization of turning process study is presented. Two output parameters of the turning process taken into consideration are surface roughness and Material Removal Rate (MRR). Taguchi method has been applied to design the experimental matrix with four input parameters including nose radius, cutting velocity, feed rate and cutting depth.Copras method has been employed to solve the multi-objective optimization problem. Finally, the optimal values of the input parameters have been determined to simultaneously ensure the two criteria of the minimum surface roughness and the maximumMRR.
\end{abstract}

\section{INTRODUCTION}

Surface roughness has a direct influence on the workability and durability of the product, and MRR is a characteristic parameter to evaluate the productivity of machining process. Therefore, ensuring the surface of workpiece with a small roughness and a large MRR is always the desire of most machining methods in general and turning methods in particular [1-3]. The MRR when turning depends on workpiece diameter, feed rate and cutting depth and the surface roughness when turning is influenced by many parameters such as cutting parameters, parameters of cutting tools, workpiece materials, coolant, stiffness of technology system, etc. Therefore, in order to simultaneously ensure the two criteria including the minimum surface roughness and the maximum MRR, it is necessary to determine the optimal values of these parameters. Because of the large number of experiments, the consideration of all these parameters in a single study will lead to a complexity Therefore, it is recommended to choose several parameters that can be easily adjusted by the machine operator. On the other hand, it is also necessary to choose the type of experimental matrix design so that the number of experiments is minimal, but it is still required to ensure the principle of experimental planning.

The experimental matrix design by Taguchi method was recommended by Dr. Genichi Taguchi in 1980 [4]. This is a very famous matrix design method that has been applied in many studies in many different fields. This method enables to design an experimental matrix with a small number of experiments and a large number of input parameters. In addition, the input parameters in qualitative form can also be included in the experimental matrix, which is an outstanding advantage that only this method has [5-8]. However, the Taguchi method has a major drawback that it can only solve the singleobjective optimization problem through the analysis of $\mathrm{S} / \mathrm{N}$ ratio (signal-to-noise).

To be able to overcome this drawback while successfully using the advantages of Taguchi method when solving the multi-objective problems, it is necessary to com-bine it with a certain mathematical method. It is possible to designate a number of other methods that have been very successful when being combined with the Taguchi method such as: the combination of Taguchi-Dear [9], Taguchi-Topsis [1016], Tagu-chi-Vikor [17-19], Taguchi-Moora [20, 21], Taguchi-PSI [22], Taguchi-RIM [23-25], etc. Copras is also a well-known method for solving the multiobjective optimization problems. This method has been applied in some cases to solve the multi-objective optimization problems such as the multi-objective optimization of mushroom growing process [26], the multi-objective optimization of grinding process [27], etc. However, in accordance with the authors of this article, so far, there have been no published studies on the application of the Taguchi-Copras method in the multi-objective optimization of turning process.

From the above analysis, in this study, the turning process experiment will be conducted with the experimental matrix designed in accordance with the Taguchi method. Copras method will be applied to solve the multi-objective optimization problem. The purpose of this study is to simultaneously ensure the minimum surface roughness and the maximum MRR.

* Corresponding author: natuan.ck@uneti.edu.vn 


\section{Multi-objective Copras method}

\subsection{Multiple criteria decision-making model}

Multiple criteria decision-making (MCDM) model helps us to choose the best option from the set of options $A=$ $\left\{\mathrm{A} \_1, \mathrm{~A} \_2, \ldots, \mathrm{A} \_\mathrm{m}\right\}$ based on the set of criteria $\mathrm{C}=$ $\left\{C_{-} 1, C_{-} 2, \ldots, C_{-} n\right\}$. Where each criterion $\mathrm{C}_{-} \mathrm{j}$ is assigned with a weight $w_{-} j(j=1,2, \ldots, n)$ so that $\sum(\mathrm{j}=1)^{\wedge} \mathrm{n}_{\mathrm{w}} \mathrm{W} \_\mathrm{j}=1$. An MCDM problem can be represented by a matrix in the form of $=\left[d_{-} i j\right] \_(m \times n)$ [28].

$A_{1}$
$A_{2}$
$\vdots$
$A_{3}$$\left[\begin{array}{cccc}d_{11} & d_{12} & d_{1 n} & d_{1 n} \\ d_{21} & d_{22} & d_{2 n} & d_{2 n} \\ \vdots & \vdots & \vdots & \vdots \\ d_{m 1} & d_{m 2} & d_{m n} & d_{m n}\end{array}\right]$

Where $d \_i j \in R^{\wedge}+$ with all $i=1,2, \ldots, m$ and $j=1,2, \ldots$, n.

In this study, the weighting of criteria will be calculated using the Entropy measure because it provides high accuracy. The weight calculation steps are performed as follows [29]:

Step 1: Calculate the values $p_{i j}$ with all $\mathrm{i}=1,2, \ldots, \mathrm{m}$ and $\mathrm{j}=1,2, \ldots, \mathrm{n}$.

$p_{i j}=\frac{d_{i j}}{m+\sum_{i=1}^{m} d_{i j}^{2}}$

Step 2: Calculate the entropy measures $e_{j}$ of each criterion $C_{j}$ with all $\mathrm{j}=1,2, \ldots, \mathrm{n}$

$\varepsilon_{j}=-\sum_{i=1}^{m}\left[p_{i j} \ln \left(p_{i j}\right)\right]-\left(1-\sum_{i=1}^{m} p_{i j}\right) \times \ln \left(1-\sum_{i=1}^{m} p_{i j}\right)$

Step 3: Calculate the weights $w_{j}$ of each criterion $C_{j}$ with all $\mathrm{j}=1,2, \ldots, \mathrm{n}$

$w_{j}=\frac{1-e_{j}}{\sum_{j=1}^{n}\left(1-e_{j}\right)}$

\subsection{Copras method}

The Copras method was first introduced by Zavadskas et al. in 1994 [30]. This method includes the following steps:

Step 1: Calculate the values $\mathrm{p}_{-} \mathrm{ij}$ in accordance with the formula (1) with all $i=1,2, \ldots, m$ and $j=1,2, \ldots, n$.

Step 2: Calculate the entropy measures $\mathrm{e}_{-} \mathrm{i}$ of each criterion $\mathrm{C} \_\mathrm{i}$ with all $\mathrm{j}=1,2, \ldots, \mathrm{n}$ in accordance with the formula (2).

Step 3: Calculate the weights $w_{\_} j$ of each criterion $C_{-} j$ with all $\mathrm{j}=1,2, \ldots, \mathrm{n}$ in accordance with the formula (3).

Step 4: Calculate the normalized decision matrix $X=$ [X_ij ] $(m \times n)$, with all $i=1,2, \ldots, m$ and $j=1,2, \ldots, n$. In which:

$$
X_{i j}=\frac{a_{i j}}{\sum_{i=1}^{m} d_{i j}}
$$

Step 5: Calculate the normalized decision matrices with the weights $\mathrm{W}=\left[\mathrm{W} \_\mathrm{ij}\right] \_(\mathrm{m} \times \mathrm{n})$, with all $\mathrm{i}=1,2, . ., \mathrm{m}$ and $\mathrm{j}=1,2, \ldots$, n. In which:

$$
W_{i j}=w_{j} \times d_{i j}
$$

Step 6: Calculate $\mathrm{P}_{\mathrm{i}} \mathrm{i}$ and $\mathrm{R}$ i with all $i=1,2, \ldots, \mathrm{m}$ and $\mathrm{j}=1,2, \ldots, \mathrm{n}$ in accordance with the following two

$$
\begin{gathered}
\quad \text { formulas: } \\
P_{\mathrm{i}}=\frac{1}{|\bar{B}|} \sum_{j \in B} W_{\mathrm{i} j} \\
R_{\mathrm{i}}=\frac{1}{|N B|} \sum_{j \in N B} W_{i j}
\end{gathered}
$$

Step 7: Calculate priority values with all $\mathrm{i}=1,2, \ldots, \mathrm{m}$ :

$$
Q_{i}=P_{i}+\frac{\sum_{i=1}^{m} R_{i}}{R_{i} \times \sum_{i=1}^{m} \frac{1}{R_{i}}}
$$

Step 8: Rank the options $A_{-} \mathrm{k}<\mathrm{A}_{-} \mathrm{i}$ if $\mathrm{Q} \mathrm{k}<\mathrm{Q} \_\mathrm{i}$ with all $\mathrm{i}$, $\mathrm{k}=1,2, \ldots, \mathrm{m}$.

\section{Experimental process}

The experiments have been conducted on CNC Doosan Lynx 220L lathe, the experimental steel has been SCM400 steel with a diameter of $28 \mathrm{~mm}$ and a length of $300 \mathrm{~mm}$. TiAlN coated insert have been used during the experiment. Four parameters including nose radius (r), cutting velocity (vc), feed rate (fd) and cutting depth (ap) have been selected as input parameters of the experimental process. These are parameters that can be easily adjusted by the machine operator.

The Taguchi method has been applied to design an orthogonal matrix with a total of 16 experiments as shown in Table 1, in which each input parameter has been selected with four levels of values.

Table 1. Orthogonal matrix L16

\begin{tabular}{|c|c|c|c|c|c|c|c|c|} 
(2) & \multicolumn{2}{|c|}{ Code value } \\
$\mathbf{0}$. & $\mathrm{r}$ & $\mathrm{v}$ & $\mathrm{f}$ & $\mathrm{a}$ & $\begin{array}{c}\mathrm{r} \\
(\mathrm{mm})\end{array}$ & $\begin{array}{c}\mathrm{vc} \\
(\mathrm{m} / \mathrm{min})\end{array}$ & $\begin{array}{c}\mathrm{f}_{\mathrm{y}} \\
(\mathrm{mm} / \mathrm{rev})\end{array}$ & $\begin{array}{c}\mathrm{a}_{\mathrm{p}} \\
(\mathrm{mm})\end{array}$ \\
\hline 1 & 1 & 1 & 1 & 1 & 0.4 & 75 & 0.06 & 0.4 \\
\hline 2 & 1 & 2 & 2 & 2 & 0.4 & 100 & 0.08 & 0.6 \\
\hline 3 & 1 & 3 & 3 & 3 & 0.4 & 125 & 0.1 & 0.8 \\
\hline 4 & 1 & 4 & 4 & 4 & 0.4 & 150 & 0.12 & 1.0 \\
\hline 5 & 2 & 1 & 2 & 3 & 0.6 & 75 & 0.08 & 0.8 \\
\hline 6 & 2 & 2 & 1 & 4 & 0.6 & 100 & 0.06 & 1.0 \\
\hline 7 & 2 & 3 & 4 & 1 & 0.6 & 125 & 0.12 & 0.4 \\
\hline 8 & 2 & 4 & 3 & 2 & 0.6 & 150 & 0.1 & 0.6 \\
\hline 9 & 3 & 1 & 3 & 4 & 0.8 & 75 & 0.1 & 1.0 \\
\hline 10 & 3 & 2 & 4 & 3 & 0.8 & 100 & 0.12 & 0.8 \\
\hline 11 & 3 & 3 & 1 & 2 & 0.8 & 125 & 0.06 & 0.6 \\
\hline 12 & 3 & 4 & 2 & 1 & 0.8 & 150 & 0.08 & 0.4 \\
\hline 13 & 4 & 1 & 4 & 2 & 1.0 & 75 & 0.12 & 0.6 \\
\hline 14 & 4 & 2 & 3 & 1 & 1.0 & 100 & 0.1 & 0.4 \\
\hline 15 & 4 & 3 & 2 & 4 & 1.0 & 125 & 0.08 & 1.0 \\
\hline 16 & 4 & 4 & 1 & 3 & 1.0 & 150 & 0.06 & 0.8 \\
\hline
\end{tabular}


Surface roughness is measured in accordance with the arithmetic mean roughness ( $R a)$. MRR is calculated in accordance with the formula (9). Where nw is the number of revolutions of the workpiece per minute, $\mathrm{dw}$ is the workpiece diameter, fd is the feed rate and ap is the cutting depth.

$$
M R R=\frac{1}{60} n_{w} \pi d_{w} f_{d} a_{p}
$$

\section{Results and discussion}

The experimental results are presented in Table 2. In this table, the minimum value of surface roughness is 0.524 $\mu \mathrm{m}$ in the experiment \#14. However, also in this experiment, the MRR is also very small $(66.67 \mathrm{~mm} 3 / \mathrm{min})$, so this experiment is not the best one. The MRR in the experiment \#4 has the largest value (300 $\mathrm{mm} 3 / \mathrm{min})$. However, also in this experiment, the surface roughness value is also very large $(1,722 \mu \mathrm{m})$, so this experiment is not also the best one. Since then, it is shown that it is impossible to find an experiment absolutely and simultaneously ensuring the two criteria of the minimum surface roughness and the maximum MRR, but it is only possible to find an experiment where the surface roughness is considered as "minimum" and the MRR is considered as "maximum". This work is incapable of being achieved by just looking at the data in Table 2, that can only be done by solving the multi-objective problem.

Table 2. Experimental results

\begin{tabular}{|c|c|c|c|c|c|c|}
\hline $\begin{array}{c}\mathrm{N} \\
0 .\end{array}$ & $\begin{array}{c}\mathrm{r} \\
(\mathrm{mm})\end{array}$ & $\begin{array}{c}\mathrm{v}_{\mathrm{c}}(\mathrm{m} / \\
\mathrm{min})\end{array}$ & $\begin{array}{c}\mathrm{f}_{\mathrm{d}} \\
(\mathrm{mm} / \mathrm{r} \\
\mathrm{ev})\end{array}$ & $\mathrm{a}_{\mathrm{p}}(\mathrm{mm})$ & $\begin{array}{c}\mathrm{Ra} \\
(\mu \mathrm{m})\end{array}$ & $\begin{array}{c}\mathrm{MRR} \\
\left(\mathrm{mm}^{3} / \mathrm{mi}\right. \\
\mathrm{n})\end{array}$ \\
\hline 1 & 0.4 & 75 & 0.06 & 0.4 & 1.822 & 30.00 \\
\hline 2 & 0.4 & 100 & 0.08 & 0.6 & 0.866 & 80.00 \\
\hline 3 & 0.4 & 125 & 0.1 & 0.8 & 0.623 & 166.67 \\
\hline 4 & 0.4 & 150 & 0.12 & 1.0 & 1.722 & 300.00 \\
\hline 5 & 0.6 & 75 & 0.08 & 0.8 & 0.941 & 80.00 \\
\hline 6 & 0.6 & 100 & 0.06 & 1.0 & 0.888 & 100.00 \\
\hline 7 & 0.6 & 125 & 0.12 & 0.4 & 1.222 & 100.00 \\
\hline 8 & 0.6 & 150 & 0.1 & 0.6 & 1.131 & 150.00 \\
\hline 9 & 0.8 & 75 & 0.1 & 1.0 & 1.240 & 125.00 \\
\hline 10 & 0.8 & 100 & 0.12 & 0.8 & 1.324 & 160.00 \\
\hline 11 & 0.8 & 125 & 0.06 & 0.6 & 0.802 & 75.00 \\
\hline 12 & 0.8 & 150 & 0.08 & 0.4 & 1.134 & 80.00 \\
\hline 13 & 1.0 & 75 & 0.12 & 0.6 & 1.234 & 90.00 \\
\hline 14 & 1.0 & 100 & 0.1 & 0.4 & 0.524 & 66.67 \\
\hline 15 & 1.0 & 125 & 0.08 & 1.0 & 0.525 & 166.67 \\
\hline 16 & 1.0 & 150 & 0.06 & 0.8 & 1.820 & 120.00 \\
\hline
\end{tabular}

\section{Multi-objective optimization turning process by Copras method}

In order to facilitate the use of mathematical symbols when performing the optimization by the Copras method, we set the criterion of Surface roughness ( $\mathrm{Ra}$ ) as $\mathrm{C} 1$, and set the criterion of MRR as $\mathrm{C} 2$ as shown in Table 3.

Table 3. Surface roughness and MRR at the experiments

\begin{tabular}{|c|c|c|}
\hline No. & $\mathrm{Ra}=\mathrm{C}_{1}$ & $\mathrm{MRR}=\mathrm{C}_{2}$ \\
\hline $\mathrm{A}_{1}$ & 1.822 & 30.00 \\
\hline $\mathrm{A}_{2}$ & 0.866 & 80.00 \\
\hline $\mathrm{A}_{3}$ & 0.623 & 166.67 \\
\hline $\mathrm{A}_{4}$ & 1.722 & 300.00 \\
\hline $\mathrm{A}_{5}$ & 0.94 & 80.00 \\
\hline $\mathrm{A}_{6}$ & 0.888 & 100.00 \\
\hline $\mathrm{A}_{7}$ & 1.222 & 100.00 \\
\hline $\mathrm{A}_{8}$ & 1.13 & 150.00 \\
\hline $\mathrm{A}_{9}$ & 1.24 & 125.00 \\
\hline $\mathrm{A}_{10}$ & 1.324 & 160.00 \\
\hline $\mathrm{A}_{11}$ & 0.802 & 75.00 \\
\hline $\mathrm{A}_{12}$ & 1.134 & 80.00 \\
\hline $\mathrm{A}_{13}$ & 1.234 & 90.00 \\
\hline $\mathrm{A}_{14}$ & 0.524 & 66.67 \\
\hline $\mathrm{A}_{15}$ & 0.525 & 166.67 \\
\hline $\mathrm{A}_{16}$ & 1.822 & 120.00 \\
\hline
\end{tabular}

From the data in Table 3, the Copras method is used to calculate the following values:

Step 1: Calculate the values $\mathrm{p} \_$ij in accordance with the formula 1. The results are presented in Table 4.

Step 2: Use the formula (2) to calculate the entropy measures $\mathrm{e}_{-} \mathrm{j}$ of each criterion $\mathrm{C}_{-} \mathrm{j}$. The results are shown in Table 5.

Step 3: Use the formula (3) to calculate the weights $\mathrm{w}_{-} \mathrm{j}$ of each criterion $\mathrm{C}_{\mathrm{j}} \mathrm{j}$. The results are also shown in Table 5.

Step 4: Use the formula (4) to calculate the normalized decision matrix, as shown in Table 6.

Step 5. Use the formula (5) to calculate the decision matrices after the normalization of number $\mathrm{W}$. The results are shown in Table 7.

Step 6. Use the formula (6) to calculate the value of Pi, use the formula (7) to calculate the value of $\mathrm{Ri}$. The results are shown in Table 8.

Step 7. Use the formula (8) to calculate the value of Qi. The results are also shown in Table 8 .

The results in Table 8 have shown that A15 is the best option, while the option A1 is the worst one out of a total of 16 conducted options. In option A1, the surface roughness is $1.822 \square \mathrm{m}$, which is the largest value of the 16 surface roughness values in Table 2. Also in this option, the MRR is equal to $30 \mathrm{~mm} 3 / \mathrm{min}$, which is the 
smallest value of the $16 \mathrm{MRR}$ values. Thus, it is obvious that A1 is the worst option. In the A15 option, the surface roughness is equal to $0.525 \square \mathrm{m}$, although it is not the minimum value of 16 options (the minimum surface roughness value is equal to $0.524 \square \mathrm{m}$ in the A14 option), the surface roughness in this option is also very small compared to the other options. The MRR in the A15 option is equal to $166.67 \mathrm{~mm} 3 / \mathrm{min}$, although this is still smaller than the MRR value in the A4 option, it is also a rather large value compared to the other options. Since then, it can be confirmed that A14 is the best option where the surface roughness is "smallest" and the MRR is "largest". Thus, the optimal values of the parameters of nose radius, cutting velocity, feed rate and cutting depth are $1 \mathrm{~mm}, 125 \mathrm{~m} / \mathrm{min}, 0.08 \mathrm{~mm} / \mathrm{rev}$ and 1 $\mathrm{mm}$, respectively.

Table 4. Table of values of $p_{i j}$

\begin{tabular}{|c|c|c|}
\hline \multirow{2}{*}{ No. } & \multicolumn{2}{|c|}{$\mathbf{p}_{\mathbf{i j}}$} \\
\cline { 2 - 3 } & $\mathbf{C}_{\mathbf{1}}$ & $\mathbf{C}_{\mathbf{2}}$ \\
\hline $\mathrm{A}_{1}$ & 0.086275 & 0.000106 \\
\hline $\mathrm{A}_{2}$ & 0.019491 & 0.000284 \\
\hline $\mathrm{A}_{3}$ & 0.010087 & 0.000591 \\
\hline $\mathrm{A}_{4}$ & 0.077065 & 0.001064 \\
\hline $\mathrm{A}_{5}$ & 0.022964 & 0.000284 \\
\hline $\mathrm{A}_{6}$ & 0.020494 & 0.000355 \\
\hline $\mathrm{A}_{7}$ & 0.038809 & 0.000355 \\
\hline $\mathrm{A}_{8}$ & 0.033185 & 0.000532 \\
\hline $\mathrm{A}_{9}$ & 0.039961 & 0.000443 \\
\hline $\mathrm{A}_{10}$ & 0.045558 & 0.000567 \\
\hline $\mathrm{A}_{11}$ & 0.016716 & 0.000266 \\
\hline $\mathrm{A}_{12}$ & 0.033421 & 0.000284 \\
\hline $\mathrm{A}_{13}$ & 0.039575 & 0.000319 \\
\hline $\mathrm{A}_{14}$ & 0.007136 & 0.000236 \\
\hline $\mathrm{A}_{15}$ & 0.007163 & 0.000591 \\
\hline $\mathrm{A}_{16}$ & 0.086275 & 0.000426 \\
\hline
\end{tabular}

Table 5. Weight of criteria

\begin{tabular}{|c|c|c|}
\hline Parameters in Copras & $\boldsymbol{C}_{\boldsymbol{1}}$ & $\boldsymbol{C}_{\boldsymbol{2}}$ \\
\hline Entropy & 2.16358 & 0.05802 \\
\hline Weight & 5.25083 & -4.25083 \\
\hline
\end{tabular}

Table 6. Normalized matrix

\begin{tabular}{|c|c|c|}
\hline \multirow{2}{*}{ No. } & \multicolumn{2}{|c|}{$\mathbf{X}_{\mathbf{i j}}$} \\
\cline { 2 - 3 } $\mathbf{C}_{\mathbf{1}}$ & $\mathbf{C}_{\mathbf{2}}$ \\
\hline $\mathrm{A}_{1}$ & 0.38430 & 0.05650 \\
\hline $\mathrm{A}_{2}$ & 0.18266 & 0.15066 \\
\hline $\mathrm{A}_{3}$ & 0.13140 & 0.31388 \\
\hline $\mathrm{A}_{4}$ & 0.36321 & 0.56498 \\
\hline
\end{tabular}

\begin{tabular}{|l|l|l|}
\hline $\mathrm{A}_{5}$ & 0.19827 & 0.15066 \\
\hline $\mathrm{A}_{6}$ & 0.18730 & 0.18833 \\
\hline $\mathrm{A}_{7}$ & 0.25775 & 0.18833 \\
\hline $\mathrm{A}_{8}$ & 0.23834 & 0.28249 \\
\hline $\mathrm{A}_{9}$ & 0.26154 & 0.23541 \\
\hline $\mathrm{A}_{10}$ & 0.27926 & 0.30132 \\
\hline $\mathrm{A}_{11}$ & 0.16916 & 0.14125 \\
\hline $\mathrm{A}_{12}$ & 0.23919 & 0.15066 \\
\hline $\mathrm{A}_{13}$ & 0.26028 & 0.16949 \\
\hline $\mathrm{A}_{14}$ & 0.11052 & 0.12556 \\
\hline $\mathrm{A}_{15}$ & 0.11073 & 0.31388 \\
\hline $\mathrm{A}_{16}$ & 0.38430 & 0.22599 \\
\hline
\end{tabular}

Table 7. The normalized matrix in combination with the weights in Table 5

\begin{tabular}{|c|c|c|}
\hline \multirow{2}{*}{ No. } & \multicolumn{2}{|c|}{$\mathbf{W}_{\mathbf{i j}}=\mathbf{w}_{\mathbf{j}} \times \mathbf{d}_{\mathbf{i j}}$} \\
\cline { 2 - 3 } & $\mathbf{C}_{\mathbf{1}}$ & $\mathbf{C}_{\mathbf{2}}$ \\
\hline $\mathrm{A}_{1}$ & 9.56701 & -127.52490 \\
\hline $\mathrm{A}_{2}$ & 4.54722 & -340.06640 \\
\hline $\mathrm{A}_{3}$ & 3.27127 & -708.48584 \\
\hline $\mathrm{A}_{4}$ & 9.04193 & -1275.24900 \\
\hline $\mathrm{A}_{5}$ & 4.93578 & -340.06640 \\
\hline $\mathrm{A}_{6}$ & 4.66274 & -425.08300 \\
\hline $\mathrm{A}_{7}$ & 6.41651 & -425.08300 \\
\hline $\mathrm{A}_{8}$ & 5.93344 & -637.62450 \\
\hline $\mathrm{A}_{9}$ & 6.51103 & -531.35375 \\
\hline $\mathrm{A}_{10}$ & 6.95210 & -680.13280 \\
\hline $\mathrm{A}_{11}$ & 4.21116 & -318.81225 \\
\hline $\mathrm{A}_{12}$ & 5.95444 & -340.06640 \\
\hline $\mathrm{A}_{13}$ & 6.47952 & -382.57470 \\
\hline $\mathrm{A}_{14}$ & 2.75143 & -283.40284 \\
\hline $\mathrm{A}_{15}$ & 2.75669 & -708.48584 \\
\hline $\mathrm{A}_{16}$ & 9.56701 & -510.09960 \\
\hline
\end{tabular}

Table 8. Pi, Ri, Qi calculation results and rankings

\begin{tabular}{|c|c|c|c|c|}
\hline No. & $\mathbf{P}_{\mathbf{i}}$ & $\mathbf{R}_{\mathbf{i}}$ & $\mathbf{Q}_{\mathbf{i}}$ & Ranking \\
\hline $\mathrm{A}_{1}$ & 9.56701 & -127.52490 & 29.44047 & 16 \\
\hline $\mathrm{A}_{2}$ & 4.54722 & -340.06640 & 11.99976 & 9 \\
\hline $\mathrm{A}_{3}$ & 3.27127 & -708.48584 & 6.84842 & 2 \\
\hline $\mathrm{A}_{4}$ & 9.04193 & - & & \\
\hline $\mathrm{A}_{5}$ & 4.93578 & -340.06640 & 12.38833 & 12 \\
\hline $\mathrm{A}_{6}$ & 4.66274 & -425.08300 & 10.62477 & 4 \\
\hline $\mathrm{A}_{7}$ & 6.41651 & -425.08300 & 12.37855 & 11 \\
\hline $\mathrm{A}_{8}$ & 5.93344 & -637.62450 & 9.90813 & 3 \\
\hline $\mathrm{A}_{9}$ & 6.51103 & -531.35375 & 11.28066 & 7 \\
\hline $\mathrm{A}_{10}$ & 6.95210 & -680.13280 & 10.67837 & 5 \\
\hline $\mathrm{A}_{11}$ & 4.21116 & -318.81225 & 12.16055 & 10 \\
\hline $\mathrm{A}_{12}$ & 5.95444 & -340.06640 & 13.40699 & 14 \\
\hline $\mathrm{A}_{13}$ & 6.47952 & -382.57470 & 13.10401 & 13 \\
\hline $\mathrm{A}_{14}$ & 2.75143 & -283.40284 & 11.69404 & 8 \\
\hline
\end{tabular}




\begin{tabular}{|l|c|c|c|c|}
\hline $\mathrm{A}_{15}$ & 2.75669 & -708.48584 & 6.33384 & 1 \\
\hline $\mathrm{A}_{16}$ & 9.56701 & -510.09960 & 14.53537 & 15 \\
\hline
\end{tabular}

\section{Conclusion}

The experimental process of turing SCM400 steel with TiAlN insert has been con-ducted on CNC lathe in accordance with the Taguchi-type experimental matrix. Nose radius, cutting velocity, feed rate and cutting depth are parameters to determine the optimal value. Surface roughness and MRR are two criteria to evaluate the turning process. The Copras method has been applied to solve the multi-objective optimiza-tion problem. A number of conclusions are drawn as follows:

In order to simultaneously ensure the two criteria including the minimum surface roughness and the maximum MRR, the value of nose radius is $1 \mathrm{~mm}$, the cutting velocity is $125 \mathrm{~m} / \mathrm{min}$, the feed rate is 0.08 $\mathrm{mm} / \mathrm{rev}$ and the cutting depth is $1 \mathrm{~mm}$.

The Copras method has been applied for the first time and succeeded in the multi-objective optimization of turning process in this study. This method has also been successful in solving the multi-objective problems in a number of published studies [26,27]. At the same time, it also promises to be successful when being applied to the multi-objective optimization of other machining processes.

Determination of the optimal set of parameters of cutting tool (materials of chip, geometrical parameters, ...) and parameters of lubricating and cooling to simultaneously ensure the criteria of turning process is the work that will be done by the authors of this article in the next time.

\section{Acknowledgment}

This work was supported by Thai Nguyen University of Technology.

\section{References}

1. Q. Xu, J. Zhao, X. Ai, The International Journal of Advanced Manufacturing Technology, 91, 1 (2017).

2. N. H. Son, H. X. Thinh, N.-T. Nguyen, D. D. Trung, European Journal of Engineering Research and Science, 4, 11 (2019).

3. D. CICA, H.CALISKAN, P. PANJAN, D. KRAMAR, Tehničkivjesnik, 27, 513 (2020).

4. https://www.investopedia.com/terms/t/taguchimethod-of-quality-control.asp

5. M.S. Phadke, Quality Engineering Using Robust Design, Printice Hall, (1989).

6. S. K. Karna, R.V. Singh, R. Sahai, International Journal of Emerging Technology and Advanced Engineering, 2, 387 (2012).

7. S. K. Karna, R. Sahai, International Journal of Mathematical, Engineering and Management Sciences, 1, 11 (2012).
8. D. D. Trung, N. V. Thien, N. -T. Nguyen, Tribology in Industry, 43, 12 (2021).

9. H.C. Liao, Y.K. Chen, International Journal of Quality \& Reliability Management, 19, 825 (2002).

10. R. Wisnuadi, R. W. Damayanti, E. Pujiyanto, , AIP Conference Proceedings, 1931, 1 (2018).

11. P. Umamaheswarrao, D.R. Raju, KNS Suman, B.R. Sankar, Acta Mechanica Malaysia (AMM), 2, 28 (2019).

12. J. Kumar, R.K. Verma, FME Transactions, 48, 628 (2020).

13. P.B. Sagar, P.D. Pantanwane, B. Rajiv, Optimisation of hard turning of M42 steel using PCR-Topsis method, in 5th International \& 26th All India Manufacturing Technology, Design and Research Conference, AIMTDR, IIT Guwahati, Assam, India, vol. 325, 1 (2014).

14. Thanikasalam, J. Elanchezhian, International Journal of Advance Science and Technology, 29, 6927 (2020).

15. S.S. Sankar, M.V. Kumar Reddy, International Journal of Engineering and Advanced Technology, 8, 76 (2019).

16. Dinh, L.C, Science \& technology development, 19, 97 (2016).

17. Gangil, M., \& Pradhan, M. K,. Materials Today: Proceedings, 5, 7486 (2018).

18. Bhuyan, R., \&Routara, B., Decision Science Letters, 5, 269 (2016).

19. Kumar, G. V. A., Reddy, D. V. V., \& Nagaraju, N., Journal on Mechanical Engineering, 8, 39 (2018).

20. Gadakh. V. S., International journal of applied engineering research, 1, 743 (2011).

21. Mesran, RivalriKristiantoHondro, Muhammad Syahrizal,AndysahPutera Utama Siahaan, Robbi Rahim, Suginam, Student Admission Assesment using Multi-Objective Optimization on the Basis of Ratio Analysis (MOORA), 4th International seminar: Research for science, technology and culture, 1-7, (2017).

22. K. Maniya, M. G. Bhatt, Materials and Design, 31, 1785 (2010).

23. E. Cables Perez, M.T.Lamata, J.L.Verdegay, Information Sciences, 337, 1 (2016).

24. J.M. Sánchez-Lozano, O. Naranjo Rodríguez, Applied Soft Computing Journal, 88, 1 (2020).

25. Mehmet Alper SOFUOĞLU, R. Aykut ARAPOĞLU, Sezan ORAK, Applied Sciences and Engineering, 18, 595 (2017).

26. Tran Trung Hieu, Nguyen Xuan Thao, Phan Trong Tien, Le Thi Minh Thuy, Journal of Vietnam Agricultural Science and Technology, 17, 322 (2019).

27. N.-T. Nguyen, D. D. Trung, Journal of Applied Engineering Science, first online, (2021). 
28. Triantaphyllou, Evangelos, Springer - Science + Busines media, (2000).

29. E. K. Zavadskas, A. Kaklauskas, V. Sarka, Technological and economic development of economy, 1, 131 (2004).

30. E. K. Zavadskas, J. Antucheviciene, P. Chatterjee, information, MPDI, (2020). 